Original Research Paper

\title{
Methane Emissions by Reed Formations on the Azov Sea Coast
}

\author{
Dmitry Nikolaevich Gar'kusha and Viktor Vladimirovich Sukhorukov \\ Southern Federal University, 344006, 105/42, Bol'shaya Sadovaya, Rostov-on-Don, Russia
}

\author{
Article history \\ Received: 10-04-2019 \\ Revised: 12-11-2019 \\ Accepted: 20-12-2019 \\ Corresponding Author: \\ Viktor Vladimirovich \\ Sukhorukov \\ Southern Federal University, \\ 344006, 105/42, Bol'shaya \\ Sadovaya, Rostov-on-Don, \\ Russia \\ Email: sukhorukov20@yandex.ru
}

\begin{abstract}
Mapping of reed zones including both single-species formations and mixed formations of reeds and cattails has been done to assess methane emissions produced by reed formations growing on the coast and adjacent areas of the Azov Sea. In particular zones full-scale experiments have been carried out in order to measure methane emissions above common reed (Phragmites australis (Cav.) Trin. ex Steud.) and lake reed (Scirpus lacustris L.) areas, which have formed the basis for calculation of methane concentration produced by reed formations of the Azov Sea. Methane fluxes above the common reed and lake reed bushings range respectively from 1.73 to $5.85 \mathrm{mg} / \mathrm{m}^{2} \mathrm{~h}$ and from 1.14 to $2.34 \mathrm{mg} / \mathrm{m}^{2} \mathrm{~h}$ and are on average in 12-22 times higher than in open water areas. The total area of the Azov Sea coast and its surroundings with reed formations is $967.4 \mathrm{~km}^{2}$ or $2.5 \%$ of the sea area with open water surface. The total amount of methane emissions from these formations is estimated to be 80 thousand $\mathrm{m}^{3}$ per day or $34.5 \%$ of the total methane emissions from the open water surface of the sea. At the same time $84 \%$ of these data fall on a single system of estuaries and the lakes between the Kuban River and Primorsko-Akhtarsk town.
\end{abstract}

Keywords: Coastal Water Plants, Phragmites australis, Scirpus Lacustris, Methane Emissions in the Atmosphere

\section{Introduction}

Vegetation plays an important role in methane cycle processes in aquatic ecosystems (Gar'kusha and Fedorov, 2016). In addition to the fact that aquatic plants can be a source of organic substances after their die-back, the decomposition of which can produce great amount of methane, living plants can have a significant impact on methanogenesis, the level of methane concentration and the methane flux rate. Analysis of the living plants that have an impact on the methane cycle processes and gas exchange at the interfaces "bottom sediments-wateratmosphere" has shown (Carmichael et al., 2014; Gar'kusha and Fedorov, 2016) that:

Firstly, plants discharge solutions and accessible organic compounds into the soils where they grow, among which root excretions (root exudates) are the most abundant (Nguyen, 2003). The exudates easily decompose; they are recycled fast and provide various microorganisms with carbon compounds, including microorganisms that are precursors of methanogenic archaea (Kankaala and Bergström, 2004; Chanton et al., 2008; Megonigal and Guenther, 2008). Moreover, root excretions force microorganisms to grow and, consequently, contribute to decomposition of previously buried organic material and the release of nutrients into the plant rhizosphere (Juutinen, 2004; Saarnio et al., 2004).

Secondly, wetland vascular plants provide indirect transportation of methane from soils (bottom sediments, peat, soils) (Tang et al., 2010; Carmichael et al., 2014) into the atmosphere through aerenchyma, which forms a continuous air space inside the plant. This makes it possible to avoid oxidation of a significant amount of methane in the system "bottom sediments - water". Aerenchyma of wetland plants is also a pipeline for oxygen, which allows this gas to diffuse through the roots into the rhizosphere and adjacent bottom sediments and, as a result, to stimulate methane oxidizing bacteria in them (Colmer, 2003; Fritz et al., 2011; Iguchi et al., 2015; Gar'kusha and Fedorov, 2016). Despite the fact that oxygen, carried to the rhizosphere, makes methane oxidation more intensive, aquatic vegetation increases methane fluxes, if compare it to the areas with an open (vegetation-free) water surface (Juutinen, 2004). This is due to the fact, that the plants carry methane much faster than it diffuses along the concentration gradient in the system "bottom sediments-water-atmosphere". However, in extreme cases methane oxidation by rhizosphere oxygen can make methane stop to emit (Fritz et al., 2011). 
Methane is carried to the environment by plant organs (roots, stems, leaves) located both under and above water (Gar'kusha and Fedorov, 2016). Since the diffusion coefficient of methane in air is significantly higher than in water (by 4 orders more (Tang et al., 2010)), it is clear that the more a plant grows out of water, the more intensively methane will be carried to the atmosphere and, accordingly, there will be less diffusion in water. In general, methane emissions vary considerably depending on the composition of the plant community (Ding et al., 2004; 2005; Bhullar et al., 2014; Fedorov et al., 2015; Gar'kusha and Fedorov, 2016). It has also been established (Bansal et al., 2015), that floating vegetation, which is not anchored to the sea bottom, carries very little amount of methane, because it does not have either aerenchyma or a communication channel with bottom sediments-the main source of methane in water reservoirs (Fedorov et al., 2007). Thus, coastal aquatic plants with aerenchyma attached to the ground and with only their lower parts submerged into water will be characterized by the greatest ability to emit methane (Gar'kusha and Fedorov, 2016).

Relatively recently, Keppler et al., (2006) have revealed a new mechanism of methane formation in the aerobic plant philosphere. Although the process of the aerobic methane formation hasn't been studied thoroughly, interrelations between gas emissions by plants and ultraviolet radiation effect on vegetation and other physiological stresses (in particular, rapid temperature change or plant damage) revealed in numerous experiments show that it is a widespread process (McLeod et al., 2008; Vigano et al., 2008; 2009; Bruggemann et al., 2009; Bruhn et al., 2009; Messenger et al., 2009; Qaderi and Reid, 2009; Nisbet et al., 2009). The effect of ultraviolet radiation and other physiological stresses on plants initiate chemical reactions in them, forming active oxygen compounds; that results in some methane emissions from methyl groups of plant pectin (and even from vegetation cellulose and lignin) as a component of cell decomposition (Keppler et al., 2008; Ghyczy et al., 2008; Messenger et al., 2009; Keppler et al., 2009).

Thus, both the direct and indirect role of vegetation in formation of methane emitted into the atmosphere is currently in no doubt. According to estimates (EPA, 2010), total global methane emissions produced by vegetation range from 4 to $69 \mathrm{Tg} /$ year. And according to more modern and detailed studies (Carmichael et al., 2014), methane emissions by vegetation are estimated to be even higher i.e. from 32 to $143 \mathrm{Tg} /$ year, which is 5$22 \%$ of its annual global emissions into the atmosphere by known natural and anthropogenic sources. At the same time, the methane emissions formed in aerobic in the plant philosphere make up about $25-42 \%$ of the total vegetation contribution, the rest coming from indirect transportation. As it can be seen from the previous estimates there is a large degree of uncertainty, since, on the one hand, little attention has been paid to the studies of contribution of methane carried by vegetation; on the other hand, researchers have only recently found aerobic methane formation in the plant philosphere (Conrad, 2009; Schlesinger and Bernhardt, 2013; Carmichael et al., 2014; Gar'kusha and Fedorov, 2016).

The Azov Sea is a semi-enclosed sea of the Atlantic Ocean basin in Eastern Europe with salinity of 1.0 to 14.5 and frequent hypoxia in the water. This is the shallowest sea in the world, being up to 13.5 meters deep. In its coastal zone and along the banks and especially in the river deltas and limans (Liman is a term used for shallow estuaries of the Black and Azov Seas. Liman can be both open and separated from the sea by a narrow strip of land), the common or southern reeds dominate (Gromov, 2012), represented by both pure (single-species) reed brushwoods and mixed reed brushings, or bulrush and cattails - plants having aerenchyma.

The purpose of this paper is to measure amount of methane emitted into the atmosphere, produced by southern reed formations, which grow in the coastal zone and along the shores of the Azov Sea, its bays and estuaries. In August 2016-2018, site mapping was done where these formations grow and also, with specially designed stationary storage chambers or traps, the field experiments were carried out to measure methane emissions produced by the southern reed (Phragmites australis (Cav.) Trin. ex Steud.) and lake reed (Scirpus lacustris L.) formations, that can be found in mixed associations of plants. Apart from estimation of methane emissions produced by the reed formations of the Azov Sea, methane emissions from the open water surface of the studied sea were measured, the previously obtained formula (Gar'kusha et al., 2011; Fedorov et al., 2015; Gar'kusha et al., 2016), that approximates dependency between methane concentration in the surface layer of water and its flux in the atmosphere was used.

This paper could be a methodological background for similar research practices on other water bodies, which will contribute to more accurate measurements of methane emissions produced by vegetation at the regional and global levels and, consequently, reduce uncertainty in modeling future climate scenarios (Arneth et al., 2010; Kirschke et al., 2013).

\section{Materials and Methods}

In preliminary investigation the space images of the Azov Sea 2016 (Google Earth) have been used in order to specify areas in the sea coastal zone and adjacent territories, presumably decoded as abundant in south reed formations. During subsequent site investigation activities on the Azov Sea coast in Rostov Region and Krasnodar Region in 2016, 2017 and 2018, the real 
conditions of the areas were compared to the ones from presumably annotated space images. Practically, all of the reed bushings (more than 95\%), decoded in preliminary investigation, were proved during site investigation activities. Besides, in many space images, due to a number of different factors (e.g., color, distance from the water's edge and the form of reed bushings), areas of the southern reeds and lake reeds were clearly distinguished.

During the 2016-2018 site investigation activities the space images of the Russian coastal areas of the Azov Sea were used in order to draw up schemes of growing reed formations according to the methods (Papchenkov, 2006). Projective cover was noted. In some areas which were most overrun with reeds and at spots full of plants, the reed formations were described. The height, a number of stems and the wet top plant biomass were calculated in mowed areas $(0.5 \times 0.5 \mathrm{~m})$ and the site was mapped. All of these, as well as the interpretation of satellite images made it possible to map the habitat of the reed formations on the Azov Sea coast and to determine their location. The samples of water and sediments at the sites were collected to calculate methane concentrations.

Similar studies of the Ukrainian Azov Sea coast were not conducted by the authors due to its inaccessibility. However, research data on the species composition of the reed formations in these areas were provided (Gromov, 2012).

At the end of August 2017, in the Yeisky Liman coastal zone (100 $\mathrm{m}$ east of Nikolaevka village) the original storage chambers or traps, specially designed with plastic supporting plane and a metal rod, plastic hoops and a plastic film, were used (Fig. 1 and Table 1). Inside each of these storage trap chambers, a small battery-powered fan was installed in order to mix air and equalize methane concentrations in its volume. Experimental measurements of methane emissions over the lake reed formations (trap 1 with a base area of 2206 $\mathrm{cm}^{2}$ and an air volume in the trap of $293422 \mathrm{~cm}^{3}$ ) and the southern reed formations (trap 2 with a base area of 908 $\mathrm{cm}^{2}$ and an air volume of $136188 \mathrm{~cm}^{3}$ ) were carried out. The accumulation period lasted from 250 to $330 \mathrm{~min}$ for traps 1 and 2, respectively. Air samples of $2.5 \mathrm{~mL}$ in volume, taken at intervals of 60 to $120 \mathrm{~min}$ from the traps with a syringe (through a plastic film), were introduced into $42 \mathrm{~mL}$ standard glass bottles, which were filled up with distilled water and a preservative to the marked point (fixed air volume was $5 \mathrm{~mL}$ ). The bottles could be used for subsequent vapor-phase analysis; they had screw-on plastic caps with holes for needle to enter, with rubber and fluoroplastic liners to seal them. In such a case each sampling was performed three times (parallel samples). Also, in all three cases, immediately after the traps had been put, blank samples were taken. The amount of methane concentration was calculated according to the certified analysis methods (Gar'kusha and
Fedorov, 2014; Gar'kusha et al., 2016) with a Chromatek-Crystal 5000.2 gas chromatograph which had an equilibrium vapor dispenser using a flame ionization detector. The methane concentration was calculated according to amount of change in methane concentration in the air phase of the trap chambers during the exposure.

In addition, methane fluxes were measured by the similar method in areas with free water surface using trap 3 (a base area is $201 \mathrm{~cm}^{2}$ and an air volume in the trap is $1250 \mathrm{~cm}^{3}$ ), which had a slightly different design described in the papers (Fedorov et al., 2007; Gar'kusha et al., 2011; Fedorov et al., 2015; Gar'kusha et al., 2016) and located in several dozens of meters from the studied coastal vegetation. While gas fluxes in areas with aquatic vegetation and a free water surface, near the traps were measured, samples from the surface water layer and from the $0-2 \mathrm{~cm}$ - bottom sediment horizon to calculate methane concentrations were taken. For traps 1 and 2 of the southern reed and lake reed bushings covered with traps, the height, a number of shoots and their dry top biomass were calculated.

Sampling of water and bottom sediments and then methane concentration data were taken according to certified analysis methods (Fedorov et al., 2007; Gar'kusha et al., 2016) with the help of a gas chromatograph "Khromatek-Crystal 5000.2" which has a metering device of equilibrium steam.

To calculate the methane emissions in the atmosphere which came from the open water surface of the Azov Sea, its bays and estuaries, as well as the deltas of large rivers flowing into it, the formula, obtained by the authors earlier from some experimental data, was used (Fedorov et al., 2007; Gar'kusha et al., 2011; Fedorov et al., 2015; Gar'kusha et al., 2016). This formula, as mentioned above, approximates dependency of methane concentration in the surface layer of water and its flux into the atmosphere and is as follows (Gar'kusha et al., 2016):

$$
\begin{aligned}
& \lg F_{\mathrm{CH} 4}=0.8763 \cdot \lg C_{C H 4}+3.7384 \\
& (r=0.72 ; n=65 ; P<0.01),
\end{aligned}
$$

Where:

$\lg F_{\mathrm{CH} 4}=$ The logarithm of methane flux from water into the atmosphere, $\mathrm{nl} / \mathrm{m}^{2}$ day

$\lg C_{\mathrm{CH} 4}=$ Logarithm of methane concentrations in water, $\mathrm{nl} / \mathrm{dm}^{3}$

This formula proved to be versatile and adequate as exemplified by various bodies of water of Rostov Region (such rivers as the Don, the Temernik, the Dead Donets and the Taganrogsky Bay) (Fedorov et al., 2007), wetland landscapes of Pskov Region (Fedorov et al., 2015) and the wastewater treatment plant of the Rostov aeration station (Gar'kusha et al., 2011). 


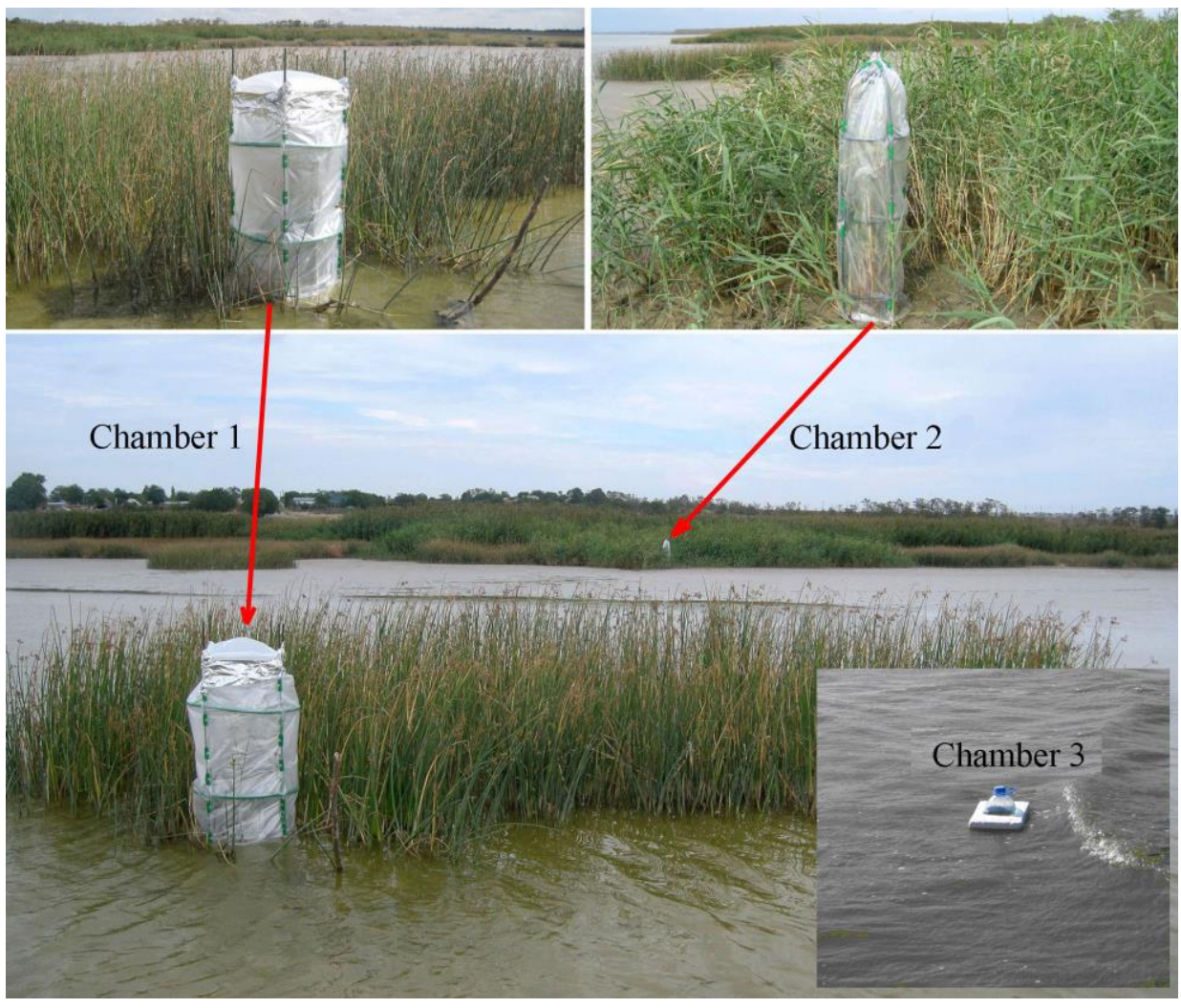

Fig. 1: Photos of accumulative chambers or traps installed to measure methane fluxes in the lake reed bushings (1), the southern reed bushings (2) and on pure water (3) in the coastal zone of the Yeisky Liman

Table 1: The methane fluxes measurements in the Yeisky Liman of the Azov Sea, August 2017

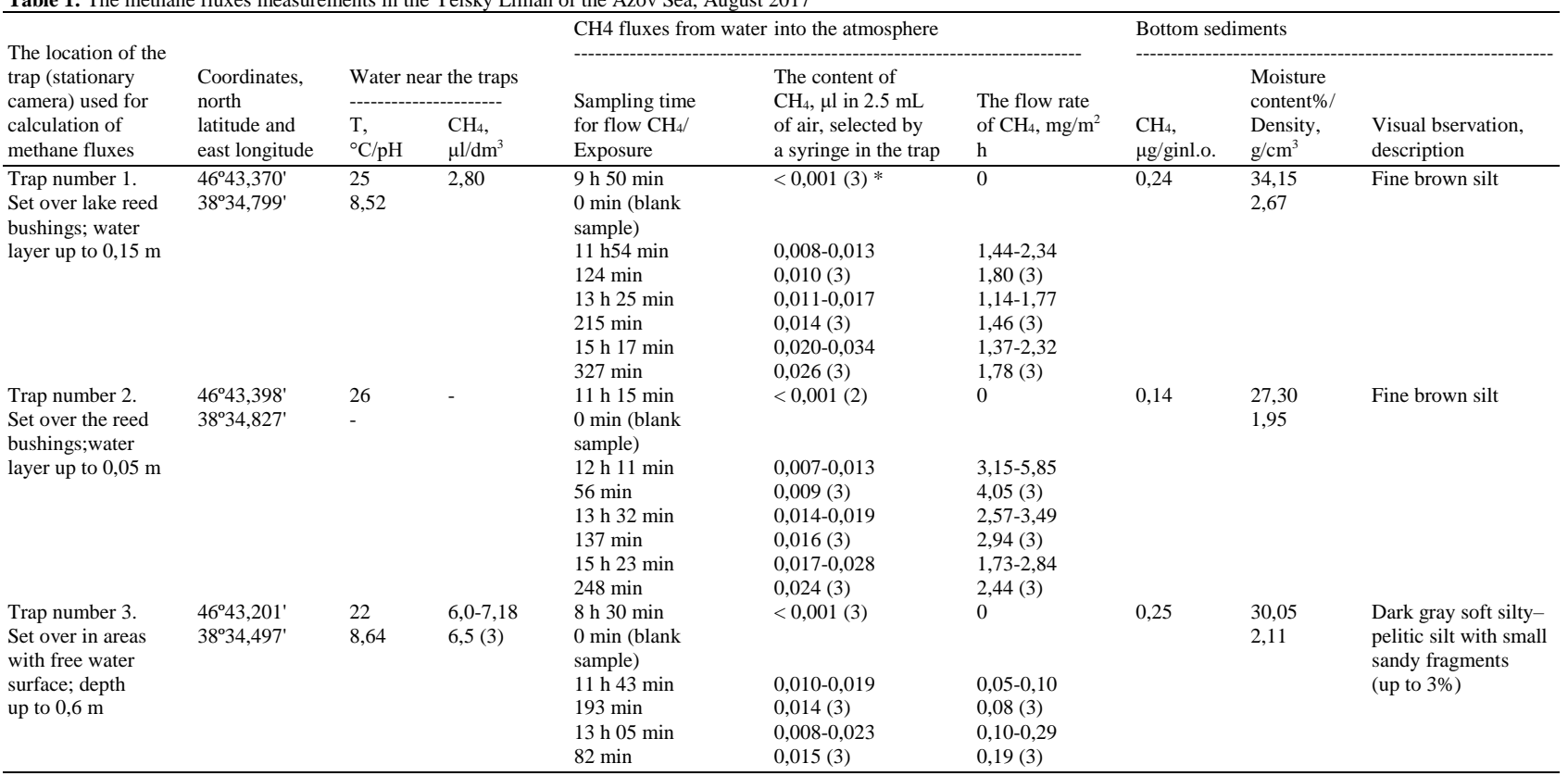

Note. * Here and in table 2 a numerator shows limits of change; a denominator is mean value; a number of measurements is in brackets

The Azov Sea water surface, its bays, estuaries, river deltas, as well as identifiable reed formations were measured with Google (2016) satellite images and the "polygon" software tool that allows one to provide accurate data of the areas of contoured space images of any shape and complexity. 


\section{Results and Discussion}

According to the research, the reed bushings, representing both pure and mixed formations of the southern reeds, are 100 meters wide in some areas directly on the Azov Sea coast. Among the pure reed bushings there are local areas (up to $2-3 \%$ of the total mapped area) (Scirpetum purum) including the southeastern coast being dominated by bulrush or lake reeds (Scirpus lacustris L.); on the northern coast threeedged reeds (Scirpus triqueter L.) prevail ((Gromov, 2012) and the present studies). In the mixed southern reed associations the most frequent, but not dominant ones (up to $15-25 \%$ of the total area of the site) are lake reeds (or bulrush) and three-edged reeds, broad-leaved cattails (Typha latifolia L.) and narrow-leaved cattails (Typha angustifolia L.) (The latter dominate among the cattails). At the same time, reed bushings occupy deeper (usually up to $0.5 \mathrm{~m}$ ) and distant places from the water edge and reeds and cattails grow both in the water and on the shore. Reeds and cattails are up to 2-3 m high, bulrush is up to $1.5 \mathrm{~m}$ high. The measured top wet biomass of the southern reeds varies within 2.6-4.5 $\mathrm{kg} / \mathrm{m}^{2}$, the one of lake reeds (bulrush) is $1.5-3 \mathrm{~kg} / \mathrm{m}^{2}$.

In shallow waters of the vast system of estuaries and lakes between the Kuban River and Primorsko-Akhtarsk town, reed roots usually grow up to $1.5 \mathrm{~m}$ deep. Being thick spaces of pure bushings, reeds cover up to $70-90 \%$; the weight of air-dry mass is about $2.97 \mathrm{~kg} / \mathrm{m}^{2}$, the stems are 3 $4 \mathrm{~m}$ high and 1.1-1.3 cm thick. Reeds and cattails are widespread here (up to 20\%), narrow-leaved cattails being predominant. As salinity of water bodies increases, the depth of reed roots decreases to $0.1-0.6 \mathrm{~m}$, the stem becomes thinner, the height decreases to $1.4-3.0 \mathrm{~m}$ and the productivity drops to $1.2-2.0 \mathrm{~kg} / \mathrm{m}^{2}$. Reed bushings are sparse at the water edge. There is no vegetation in highly saline areas and when they dry out, salty spots appear.

Calculations show (Fig. 2 and Table 2), that the total area of the Azov Sea coast and adjacent territories, overrun with reed bushings, is $967.4 \mathrm{~km}^{2}$ or $2.5 \%$ of the sea with open water surface. At the same time, $84 \%$ of this value falls on a single system of estuaries and lakes between the Kuban River and Primorsko-Akhtarsk town. Among other regions, which are considerably overrun with reed formations, one can pick up the sea edge of the Don River delta (bushings area is $50 \mathrm{~km}^{2}$ ), the Akhtarsky Liman $\left(31.6 \mathrm{~km}^{2}\right)$, the Akhtanizovsky Liman $\left(19.3 \mathrm{~km}^{2}\right)$, connected to the Azov Sea by the narrow Peresypsky Strait, the Taganrogsky Bay with the Yeysky Liman and the Miussky Liman $\left(14.5 \mathrm{~km}^{2}\right)$, the Yasensky Bay $(12.2$ $\mathrm{km}^{2}$ ), the Beysugsky Liman $\left(12.0 \mathrm{~km}^{2}\right)$, connected to the Azov Sea by the narrow Yasensky Strait, a system of lakes and estuaries at the mouth of the Byrd River (10.6 $\mathrm{km}^{2}$ ), the straits and the channels connecting the Azov Sea with Lake Sivash $\left(4.4 \mathrm{~km}^{2}\right)$.

If one does not take into account the system of estuaries and lakes between the Kuban River and
Primorsko-Akhtarsk town, the river deltas, as well as the estuaries, which are separated from the sea by bays and connected with the sea only through narrow straits (the Akhtanizovsky Liman, the Beysugsky Liman, the Miussky Liman), the area of the Azov Sea, overrun with reed formations is $56.7 \mathrm{~km}^{2}$. These reed bushings are located in the coastal zone of the Akhtarsky Liman, the Yasensky and Taganrogsky bays with the Yeisky Liman.

The reed formations of the southern and northern coasts of the Taganrogsky Bay (excluding the sea edge of the Don River delta, the Yeisky Liman and Miussky Liman) cover $0.7 \mathrm{~km}^{2}$ and $7.7 \mathrm{~km}^{2}$, respectively, with the vastest zones of reed bushings being concentrated in the eastern part of the Taganrogsky Bay, waters of which are fresher.

In general, the distribution of reed formations is controlled mainly by the depth and salinity of waters, as well as the content of nutrients (mainly nitrogen and phosphorus compounds) (Gromov, 2012). In this regard, the areas, overrun with reeds most, are typical for fresh and poorly salted, shallow water areas and usually coincide with river confluence zones, which are suppliers of biogenic components.

The methane concentration in the Azov Sea and its water bodies varies within $0.7-94.5 \mu \mathrm{l} / \mathrm{dm}^{3}$ (average is $3.1 \mu \mathrm{l} / \mathrm{dm}^{3}$ ) (Table 2). Minimum methane concentrations are typical for open sea areas, which are long distance from the coast. The maximum ones are for the zone where the Don River flows into the Taganrogsky Bay (Gar'kusha et al., 2016), as well as for shallow, wellheated estuaries, separated from the Azov Sea by bay bars and which are connected with the sea only through narrow channels (the Akhtanizovsky Liman and the Miussky Liman). The measured methane concentration significantly exceeds its equivalent concentrations (Gar'kusha et al., 2016), which indicates that methane comes from water into the atmosphere.

The calculations made according to the formula (1), which approximates the dependence between the methane concentration in the surface water layer and its flow into the atmosphere, showed that methane emissions from the water surface of the Azov Sea, including all adjacent water bodies, are 242.6 thousand m3/day (Table 2 ). At the same time, $56.4 \%$ of this value fall to the open areas of the Azov Sea directly, $28.3 \%$ belongs to the Taganrog Bay with the Yeisky Liman, $11.9 \%$ is for the system of estuaries, lakes, rivers and canals between the Kuban River and Primorsko-Akhtarsk town.

According to the experimental measurements (Table 1), methane fluxes over the southern reed formations varied within 1.73-5.85 $\mathrm{mg} / \mathrm{m}^{2}$ per $\mathrm{h}$ and were, on average, 2 times higher than their flows over the lake reed formaations (or bulrush) i.e., 1.14-2.34 mg/m² per $\mathrm{h}$. The obtained measurements are a little bit less than the methane emission indices in the boggy area (the USA) where broad-leaved cattails grow $\left(16.04 \mathrm{mg} / \mathrm{m}^{2} \mathrm{~h}\right.$ ) 
(Knapp and Yavitt, 1992) and are comparable to its emissions over reed brushings in the reservoir located in the floodplain of the Yamuna River $\left(2.6-6.4 \mathrm{mg} / \mathrm{m}^{2} \mathrm{~h}\right.$ ) (Bansal et al., 2015), as well as over reed brushwoods in the tidal swamp located in the Min River Delta (2.08$5.13 \mathrm{mg} / \mathrm{m}^{2} \mathrm{~h}$ (Tong et al., 2010). In open water surface areas the methane flux varied $0.05-0.29 \mathrm{mg} / \mathrm{m}^{2}$ per $\mathrm{h}$, which is on average 12-22 times lower than over the vegetation studied in this paper. The high emissions of the studied gas produced by reed bushings, despite relatively low concentrations of methane in water and the upper $0-2 \mathrm{~cm}$ layer of sediments in the area where they grow, is probably due to the additional transportation of methane by the root systems and plant stems from lower sediment horizons, usually containing higher methane concentrations (Fedorov et al., 2007).

Trap 1 contained 50 green reed stalks which were 20 to $120 \mathrm{~cm}$ long; their diameter at the bottom was 0.6 to $1.7 \mathrm{~cm}$, with 15 dry stalks. Trap 2 had 25 green reed stalks, 110 to $180 \mathrm{~cm}$ long and with a diameter 0.7 to 1.0 $\mathrm{cm}$, without dry stalks. The top biomass of reed and bulrush, respectively, in traps 1 and 2 was 0.6 and 0.75 $\mathrm{kg}$. If calculate the measured methane fluxes over lake reed bushings and southern reed formations regarding the number of stems that are in traps 1 and 2 during the exposure, then each stem of these plants, respectively, will account for an average 0.034 and $0.126 \mathrm{mg} / \mathrm{h}$ of methane released. That is, the southern reed stem is in 3.7 times more efficient in terms of transporting methane than the lake reed stem. When calculate the weight of top biomass, methane emissions produced by lake reed and bulrush formations are on average 2.7 and $4.2 \mathrm{mg} / \mathrm{h}$ per 1 $\mathrm{kg}$ of stems, respectively.

If the methane emission rate from the surface of the coastal areas overrun with reeds $\left(104.6 \mathrm{~km}^{2}\right)$, including the sea's bays and estuaries (except for the sea edge of the Don Delta and the system of estuaries and lakes located between the Kuban River and PrimorskoAkhtarsk town) is its average flux over the reed bushings of the southern reed and bulrush as $2.41 \mathrm{mg} / \mathrm{m}^{2}$ per $\mathrm{h}$ (or $57.9 \mathrm{mg} / \mathrm{m}^{2}$ per day), then the total methane emissions produced by reed formations will be only 8.7 thousand $\mathrm{m}^{3}$ per day or $4.1 \%$ of the total methane emissions produced by the open water surface of the Azov Sea (Table 2). If the entire area of the Azov Sea $\left(967.4 \mathrm{~km}^{2}\right)$, overrun with reed formations, including the sea edge of the Don Delta and the system of estuaries and lakes between r. Kuban and Primorsko-Akhtarsk town is taken into account when measurements are done, the total methane emissions produced by reed formations will be 80 thousand $\mathrm{m}^{3}$ (56 thousand $\mathrm{kg}$ ) per day or $34.5 \%$ of the total methane emissions produced by the open water surface of the sea.

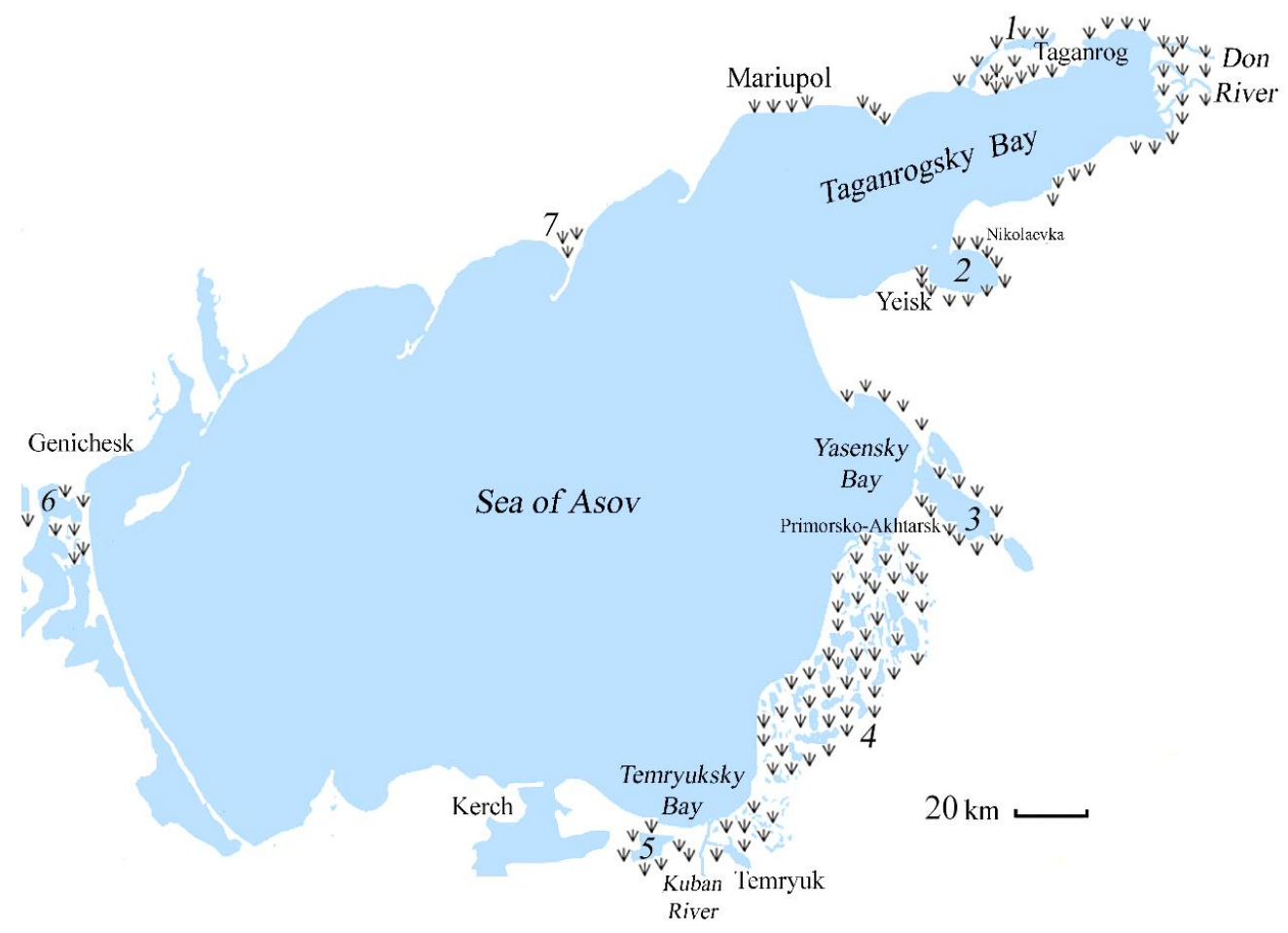

Fig. 2: Sketch map of the southern reed formations on the Azov Sea coast and adjacent areas: 1-the Miussky Liman; 2-the Yeysky Liman; 3-the Beysugsky Liman; 4-a system of estuaries and lakes between the Kuban River and Primorsko-Akhtarsk town; 5-the Akhtanizovsky Liman; 6-channels and straits connecting the Azov Sea with Lake Sivash; 7-a system of lakes and estuaries at the mouth of the Berd River 
Table 2: The open areas of the Azov Sea and the areas covered with reed bushings and methane emissions into the atmosphere

\begin{tabular}{|c|c|c|c|c|c|}
\hline \multirow[b]{2}{*}{$\begin{array}{l}\text { Water areas of the } \\
\text { Azov Sea and } \\
\text { adjacent areas }\end{array}$} & \multicolumn{2}{|c|}{ Water area, $\mathrm{km}^{2}$} & \multirow[b]{2}{*}{$\begin{array}{l}\mathrm{CH}_{4} \text { content in } \\
\text { the water column, } \\
\mu \mathrm{l} / \mathrm{dm}^{3}\end{array}$} & \multicolumn{2}{|c|}{$\mathrm{CH}_{4}$ emission into the atmosphere from water, $\mathrm{m}^{3} /$ day } \\
\hline & $\begin{array}{l}\text { From an open } \\
\text { water surface }\end{array}$ & $\begin{array}{l}\text { Covered with } \\
\text { reed formations }\end{array}$ & & $\begin{array}{l}\text { From open water } \\
\text { surface (calculated by } \\
\text { the formula (1)) }\end{array}$ & $\begin{array}{l}\text { Covered with } \\
\text { reed formations }\end{array}$ \\
\hline $\begin{array}{l}\text { Sea edge of the Don } \\
\text { River delta }\end{array}$ & 23,0 & 50,0 & $\begin{array}{l}2,2-91,2 \\
39,9(14)\end{array}$ & 1355 & 4136 \\
\hline $\begin{array}{l}\text { Taganrogsky Bay } \\
\text { without the Yeisky } \\
\text { Liman and the Miussky } \\
\text { Liman }\end{array}$ & 5289,3 & 8,4 & $6,8 *$ & 66104 & 695 \\
\hline The Miussky Liman & 65,2 & 1,6 & $\begin{array}{l}7,4-40,5 \\
17,9(5)\end{array}$ & 1903 & 132 \\
\hline The Yeysky Liman & 239,4 & 4,5 & $\begin{array}{l}2,8-7,2 \\
5,5(4)\end{array}$ & 2484 & 372 \\
\hline The Yasensky Bay & 184,4 & 12,2 & $\begin{array}{l}0,7-1,6 \\
1,1(4)\end{array}$ & 467 & 1009 \\
\hline The Beysugsky Liman & 268,8 & 12,0 & $\begin{array}{l}1,0-2,4 \\
1,6(4)\end{array}$ & 945 & 993 \\
\hline The Akhtarsky Liman & 31,1 & 31,6 & $\begin{array}{l}1,2-2,2 \\
1,7(5)\end{array}$ & 115 & 2614 \\
\hline $\begin{array}{l}\text { The system of estuaries, } \\
\text { lakes, rivers and canals } \\
\text { between the Kuban River } \\
\text { and Primorsko-Akhtarsk town }\end{array}$ & 564,7 & 812,8 & $\begin{array}{l}7,2-77,8 \\
33,9(12)\end{array}$ & 28842 & 67230 \\
\hline The Akhtanizovsky Liman & 91,8 & 19,3 & $\begin{array}{l}10,2-94,5 \\
28,0(9)\end{array}$ & 3965 & 1596 \\
\hline $\begin{array}{l}\text { Bays and the straits connecting } \\
\text { the Azov Sea with Lake Sivash } \\
\text { (near Genichesk) }\end{array}$ & 13,0 & 4,4 & $6,8 * *$ & 163 & 364 \\
\hline $\begin{array}{l}\text { The system of lakes and estuaries } \\
\text { at the mouth of the Berd River }\end{array}$ & 0,5 & 10,6 & $6,8 * *$ & 6 & 877 \\
\hline $\begin{array}{l}\text { The Azov Sea without the sea } \\
\text { edge of the Don River delta } \\
\text { and the system of estuaries, } \\
\text { lakes, rivers and canals } \\
\text { between the Kuban River } \\
\text { and Primorsko-Akhtarsk town }\end{array}$ & 38175,3 & 104,6 & $2,7 *$ & 212367 & 8652 \\
\hline $\begin{array}{l}\text { The Azov Sea totally with } \\
\text { adjacent areas }\end{array}$ & 38763,0 & 967,4 & 3,1 & 242564 *** & $80018 * * *$ \\
\hline
\end{tabular}

\section{Conclusion}

The Azov sea coast is dominated by reed formations of both pure (single-species) southern reed bushings and mixed associations in which the southern reeds, bulrush, three-edged reeds, broad-leaved and narrow-leaved cattails grow all together. The total area of the sea coast and adjacent territories, overrun with reed formations, is $967.4 \mathrm{~km}^{2}$ or $2.5 \%$ of the area of the sea with open water surface. At the same time $84 \%$ of this value falls on a single system of estuaries and lakes between the Kuban River and Primorsko-Akhtarsk town. The area, covered with red formations only on the Azov Sea coast is $56.7 \mathrm{~km}^{2}$. These reed bushings are found in the coastal zone of the Akhtarsky Liman, the Yasensky and Taganrogsky bays.

Experimentally measured methane fluxes over the southern and lake reed formations vary, respectively, in the range from 1.73 to $5.85 \mathrm{mg} / \mathrm{m}^{2}$ per $\mathrm{h}$ and from 1.14 to $2.34 \mathrm{mg} / \mathrm{m}^{2}$ per $\mathrm{h}$ and on average $12-22$ times higher than in the water surface areas with no vegetation. At the same time, the southern reed stem is 3.7 times more efficient in carrying methane than the bulrush stem.

The total amount of methane emissions from areas, overrun with reed formations $\left(104.6 \mathrm{~km}^{2}\right)$, including its bays and estuaries, including separated ones from the sea (except the system of estuaries and lakes between the Kuban River and Primorsko-Akhtarsk town of and the sea edge of the Don Delta), is 8.7 thousand $\mathrm{m}^{3}$ per day or $4.1 \%$ of the total methane emissions, produced by the open water surface of the Sea of Azov. However, if one takes into account the huge areas of reed formations, belonging to the system of estuaries and lakes between the Kuban River and Primorsko-Akhtarsk town of, as well as to the sea edge of the Don Delta, the total methane emissions of the reed formations are estimated to be 80 thousand $\mathrm{m}^{3}$ (56 thousand $\mathrm{kg}$ ) per day or $34.5 \%$ of its total emissions by the open water surface of the Azov Sea. 
Further research activities should be aimed at studying seasonal dynamics of methane emissions by reed formations growing on the coast and adjacent areas of the Azov Sea to assess the annual methane emissions produced by these plants. The important trend could evaluation of contribution of individual plant species (cattail, reed and bulrush) to the total methane emissions, included the reed formations. An important subject area for future research is also the assessment of vegetation contribution to the total methane emissions, carried to the atmosphere indirectly and the methane fluxes formed in the aerobic plants philosphere.

\section{Acknowledgement}

The work was done thanks to financial support of Southern Federal University.

\section{Author's Contribution}

Dmitry Nikolaevich Gar'kusha: The head of the research project, who designed the research plan and organized the study, coordinated the data analysis and contributed to the writing of the manuscript.

Viktor Vladimirovich Sukhorukov: Participated in all experiments, collected the field data and contributed to the writing of the manuscript.

\section{Ethics}

This article is original and contains material that hasn't been published before. The corresponding author confirms that all the other authors have read and approved the manuscript and no ethical issues have been involved.

\section{References}

Arneth, A., S.P. Harrison, S. Zaehle, K. Tsigaridis and S. Menon et al., 2010. Terrestrial biogeochemical feedbacks in the climate system. Nature Geosci., 3: 525-532. DOI: 10.1038/ngeo905

Bansal, S., M. Chakraborty, D. Katyal and J.K. Garg, 2015. Methane flux from a subtropical reservoir located in the floodplains of river Yamuna, India. Applied Ecol. Environ. Res., 13: 597-613.

DOI: 10.15666/aeer/1302_597613

Bhullar, G.S., P.J. Edwards and H. Olde Venterink, 2014. Influence of different plant species on methane emissions from soil in a restored swiss wetland. PLoS ONE, 9: e89588-e89588.

DOI: 10.1371/journal.pone.0089588

Bruggemann, N., R. Meier, D. Steigner, I. Zimmer and S. Louis et al., 2009. Nonmicrobial aerobic methane emissions from poplar shoot cultures under lowlight conditions. New Phytologist, 182: 912-918. DOI: $10.1111 / \mathrm{j} .1469-8137.2009 .02797 . x$
Bruhn, D., T.N. Mikkelsen, J. Obro, W.G.T. Willats and P. Ambus, 2009. Effects of temperature, ultraviolet radiation and pectin methyl esterase on aerobic methane release from plant material. Plant Biol., 11: 43-48. DOI: 10.1111/j.1438-8677.2009.00202.x

Carmichael, M.J., E.S. Bernhardt, S.L. Brauer and W.K. Smith, 2014. The role of vegetation in methane flux to the atmosphere: Should vegetation be included as a distinct category in the global methane budget. Biogeochemistry, 119: 1-24.

DOI: 10.1007/s10533-014-9974-1

Chanton, J.P., P.H. Glaser, L.S. Chasar, D.J. Burdige and M.E. Hines et al., 2008. Radiocarbon evidence for the importance of surface vegetation on fermentation and methanogenesis in contrasting types of boreal peatlands. Global Biogeochem. Cycles, 22: GB4022-GB4022.

DOI: $10.1029 / 2008 G B 003274$

Colmer, T.D., 2003. Long-distance transport of gases in plants: A perspective on internal aeration and radial oxygen loss from roots. Plant Cell Environ., 26: 17-36. DOI: 10.1046/j.1365-3040.2003.00846.x

Conrad, R., 2009. The global methane cycle: Recent advances in understanding the microbial processes involved. Environ. Microbiol. Rep., 1: 285-292. DOI: 10.1111/j.1758-2229.2009.00038.x

Ding, W., Z. Cai and H. Tsuruta, 2004. Summertime variation of methane oxidation in the rhizosphere of a Carex dominated freshwater marsh. Atmospheric Environ., 38: 4165-4173.

DOI: 10.1016/j.atmosenv.2004.04.022

Ding, W., Z. Cai and H. Tsuruta, 2005. Plant species effects on methane emissions from freshwater marshes. Atmospheric Environ., 39: 3199-3207. DOI: $10.1016 /$ j.atmosenv.2005.02.022

EPA, 2010. Methane and Nitrous Oxide Emissions from Natural Sources. U.S.-Environmental Protection Agency Office of Atmospheric Programs, Washington, DC, USA, pp: 194.

Fedorov, Y.A., D.N. Gar'kusha and G.V. Shipkova, 2015. Methane emissions from peat deposits of raised bogs in Pskov oblast. Geography Natural Res., 36: 70-78. DOI: 10.1134/S1875372815010102

Fedorov, Y.A., N.S. Tambieva, D.N. Gar'kusha and V.O. Khoroshevskaya, 2007. Methane in Aquatic Ecosystems. 2nd Edn., Rostizdat CJSC, Rostov-onDon-Moscow. pp: 330.

Fritz, C., V.A. Pancotto, J.T.M. Elzenga, E.J.W. Visser and A.P. Grootjans et al., 2011. Zero methane emissions bogs: Extreme rhizosphere oxygenation by cushion plants in Patagonia. New Phytol., 190: 398-408. DOI: 10.1111/j.1469-8137.2010.03604.x 
Gar'kusha, D.N. and Y.A. Fedorov, 2014. Methane in water and bottom sediments of the mouth area of the Severnaya Dvina river during the winter time. Oceanology, 54: 160-169. DOI: $10.1134 / \mathrm{S} 000143701402009 \mathrm{X}$

Gar'kusha, D.N. and Y.A. Fedorov, 2016. Effect of plants on processes of methane cycle in bottom deposits and soil rhizosphere. Contemporary Problems Ecol., 9: 771-782.

DOI: $10.1134 / \mathrm{S} 1995425516060032$

Gar'kusha, D.N., Y.A. Fedorov and A.S. Pligin, 2011. Methane emissions at the main stages of technological cycle of sewage waste water purification at Rostov-on-don aeration station. Russian Meteorol. Hydrol., 36: 453-459. DOI: $10.3103 / \mathrm{S} 1068373911070041$

Gar'kusha, D.N., Y.A. Fedorov and N.S. Tambieva, 2016. Computing the methane cycle elements in the aquatic ecosystems of the sea of AZOV and the world ocean based on empirical formulae. Russian Meteorol. Hydrol., 41: 410-417. DOI: $10.3103 / \mathrm{S} 1068373916060054$

Ghyczy, M., C. Torday, J. Kaszaki, A. Szabo and M. Czobel et al., 2008. Hypoxia-induced generation of methane in mitochondria and eukaryotic cells-an alternative approach to methanogenesis. Cellular Physiol. Biochem., 21: 251-258. DOI: $10.1159 / 000113766$

Gromov, V.V., 2012. Water and coastal aquatic vegetation of the northern and western shores of the Azov Sea. J. Siberian Federal Univ. Series: Biol., 5: 121-137. DOI: 10.17516/1997-1389-0140

Iguchi, H., H. Yurimoto and Y. Sakai, 2015. Interactions of methylotrophs with plants and other heterotrophic bacteria. Microorganisms, 3: 19-151. DOI: 10.3390/microorganisms3020137

Juutinen, S., 2004. Methane fluxes and their environmental controls in the littoral zone of boreal lakes. PhD Dissertations in Biology, University of Joensuu.

Kankaala, P. and I. Bergström, 2004. Emission and oxidation of methane in equisetum fluviatile stands growing on organic sediment and sand bottoms. Biogeochemistry, 67: 21-37.

DOI: 10.1023/B:BIOG.0000015277.17288.7a

Keppler, F., J.T.G. Hamilton, M. Brass and T. Rockmann, 2006. Methane emissions from terrestrial plants under aerobic conditions. Nature, 439: 187-191. DOI: 10.1038/nature04420

Keppler, F., J.T.G. Hamilton, W.C. McRoberts, I. Vigano and M. Brass et al., 2008. Methoxyl groups of plant pectin as a precursor of atmospheric methane: Evidence from deuterium labelling studies. New Phytol., 178: 808-814.

DOI: $10.1111 / \mathrm{j} .1469-8137.2008 .02411 . \mathrm{x}$
Keppler, F., M. Boros, C. Frankenberg, J. Lelieveld and A. McLeod et al., 2009. Methane formation in aerobic environments. Environ. Chem., 6: 459-465. DOI: $10.1071 /$ EN09137

Kirschke, S., P. Bousquet, P. Ciais, M. Saunois and J.G. Canadell et al., 2013. Three decades of global methane sources and sinks. Nature Geosci., 6: 813-823. DOI: 10.1038/ngeo1955

Knapp, A.K. and J.B. Yavitt, 1992. Evaluation of a closed-chamber method for estimating methane emissions from aquatic plants. Tellus, 44B: 63-71. DOI: 10.1034/j.1600-0889.1992.00006.x

McLeod, A.R., S.C. Fry, G.J. Loake, D.J. Messenger and D.S. Reay et al., 2008. Ultraviolet radiation drives methane emissions from terrestrial plant pectins. New Phytol., 180: 124-132.

DOI: $10.1111 / \mathrm{j} .1469-8137.2008 .02571 . \mathrm{x}$

Megonigal, J.P. and A.B. Guenther, 2008. Methane emissions from upland forest soils and vegetation. Tree Physiol., 28: 491-498. DOI: $10.1093 /$ treephys/28.4.491

Messenger, D.J., A.R. McLeod and S.C. Fry, 2009. The role ofultraviolet radiation, photosensitizers, reactive oxygen species and ester groups in mechanisms of methane formation from pectin. Plant Cell Environ., 32: 1-9. DOI: 10.1111/j.1365-3040.2008.01892.x

Nguyen, C., 2003. Rhizodeposition of organic C by plants: Mechanisms and controlsю. Agronomie, 23: 375-396. DOI: 10.1051/agro:2003011

Nisbet, R.E.R., R. Fisher, R.H. Nimmo, D.S. Bendall and P.M. Crill et al., 2009. Emission of methane from plants. Proc. Royal Society: Biol. Sci., 276: 1347-1354. DOI: 10.1098/rspb.2008.1731

Papchenkov, V.G., 2006. Mapping the vegetation cover of water bodies and watercourses. Proceedings of the 6 All-Russian School-Conference on Water Macrophytes Hydrobotany, Oct. 11-16, Rybinsk House of the Press OJSC, Rybinsk pp: 135-142.

Qaderi, M.M. and D.M. Reid, 2009. Methane emissions from six crop species exposed to three components of global climate change: Temperature, ultraviolet-B radiation and water stress. Physiol. Plantarum., 137: 139-147. DOI: 10.1111/j.1399-3054.2009.01268.x

Saarnio, S., L. Wittenmayer and W. Merbach, 2004. Rhizospheric exudation of Eriophorum vaginatum L.-potential link to methanogenesis. Plant Soil, 267: 343-355. DOI: 10.1007/s11104-005-0140-3

Schlesinger, W.H. and E.S. Bernhardt, 2013. Biogeochemistry: An Analysis of Global Change. 3rd Edn., Academic Press, ISBN-10: 0123858747, pp: 672.

Tang, J., Q. Zhuang, R.D. Shannon and J.R. White, 2010. Quantifying wetland methane emissions with process-based models of different complexities. Biogeosciences, 7: 3817-3837. DOI: $10.5194 / \mathrm{bg}-7-3817-2010$ 
Tong, C., W.Q. Wang, C.S. Zeng and R. Marrs, 2010. Methane (CH4) emission from a tidal marsh in the Min River estuary, southeast China. J. Environ. Sci. Health, Part A, 45: 506-516. DOI: $10.1080 / 10934520903542261$

Vigano, I., H. van Weelden, R. Holzinger, F. Keppler and A. McLeod et al., 2008. Effect of UV radiation and temperature on the emission of methane from plant biomass and structural components. Biogeosciences, 5: 937-947.

DOI: $10.5194 /$ bg-5-937-2008
Vigano, I., T. Rockmann, R. Holzinger, A. van Dijk and F. Keppler et al., 2009. The stable isotope signature of methane emitted from plant material under UV irradiation. Atmospheric Environ., 43: 5637-5646. DOI: 10.1016/j.atmosenv.2009.07.046 